\section{TOARNICZKY Andrea}

\section{A SZERVEZETI SZOCIALIZÁCIÓ (I. RÉSZ)-}

\author{
MI AZ IDŐ ÉS KONTEXTUS SZEREPE A SZOCIALIZÁCIÓS \\ FOLYAMATBAN?
}

Jelen cikk célja a szervezeti szocializáció szakirodalmának áttekintése és rendszerezése a következô négy kérdés mentén: (1) a „Mit értïnk szervezeti szocializáció alatt?” kérdésre keresve a választ definiálom a szocializációt, és a kapcsolódó fogalmak tárgyalása révén azt is tisztázom, hogy mi nem tekinthetố annak; (2) a „Mi az idó szerepe a szocializációs folyamatban?” kérdés mentén tárgyalom a folyamat idóben való meghatározottságát (véges vs. folytonos), valamint az idố természetének a jelentő́ségét (lineáris vs. ciklikus); (3) az „Egy vagy több?” kérdés a szervezeti kontextus egységes vagy töredezett jellegének a szocializációs folyamatra gyakorolt hatására világít rá, valamint (4) a „Mi az egyén szerepe a saját szocializációs folyamatában?” kérdés során pedig azt vizsgálom, hogy mit jelent a folyamat szempontjából, ha az egyénre, mint passzív, befogadó, vagy mint aktív, alakító szereplớre tekintünk.

Kulcsszavak: szervezeti szocializáció, identitás munka

A szervezeti szocializáció viszonylag fiatal kutatási területe meglepóen sokszínú és gazdag szakirodalommal rendelkezik, melyet részben a különböző társadalomtudományi gyökerek sikeres ötvözése, részben a fogalon folyamatosan megújuló értelmezése magyaráz. Jelen cikk célja a releváns szakirodalom áttekintése, valamint ezen megújulást megragadó fordulópontok azonosítása. Első lépésben a „Mit értünk szervezeti szocializáció alatt?" kérdésre keresem a választ mintegy kijelölve azon kutatási színteret, amelynek rendszerezó áttekintése a cikk központi célja. Ugyanitt ismertetem a fogalom kialakulásának történetét, majd megkïlönböztetem a szervezeti szocializációt a szakmai szocializációtól, valamint az akkulturáció és szervezeti identifićció fog ciórió fog mat terület változásait a következő három tengely mentén
vázolom fel:

(1) Az idố tengely: a „Mi az idó szerepe a szocializációs folyamatban?" kérdés mentén tárgyalom a

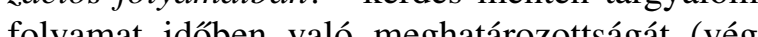
vs. folytonos), valumint az idő́t természének a jelentôségét (lineáris vs ciklikus).

(2) A szervezeti kontextus tengely: az „Egy vagy több?" kérdés a szervezeti kontextus egységes vagy töredezett jellegének a szocializációs folyamatra gyakorolt hatására világít rá

(3) Az aktív együttmúködés (agency) tengely: a „Mi az egyén szerepe a saját szocializációs folyamatájelent a folyamat szempontjából, ha az egyénre mint lốre tekintünk.

\section{Mit értünk szervezeti szocializáció alatt?}

A szocializáció központi kérdése - milyen folyamat(ok) során alakul át az emberi szervezet (mint biológiai entitás) személlyé (azaz társas és mos tudományteri

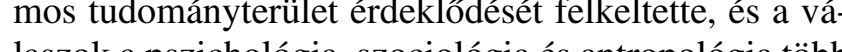

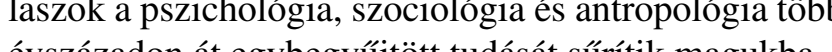
Gyökerek: a szocializáció fogalma a társadalomtudományokban

A szocializációra vonatkozó korai kutatások a pszichológia területén folytak, ahol azt lineáris, egymásra épüló szakaszokból álló, kognitív fejlódési folyamatként ábrázolják, s funkcionalista indíttatással arra törekszenek, hogy megmagyarázzák, hogy a gyerekek miként ban?" kérdés során pedig azt vizsgálom, hogy mit passzív, befogadó, vagy mint aktív, alakító szerep- fejlődnek kompetens felnôtté (Lutfey - Mortimer, 2003). Ezeknek az elméleteknek komoly hiányossága, hogy idôben a gyermekkorra korlátozódnak és feltételezik, hogy a folyamat eredménye egy jól múködő felnőt (aki nem szorul további szocializációra); valamint hogy számolhatunk egy egyetemes, lineáris fejlődési sor létezésével ${ }^{1}$. Az antropológusok ezzel szemben a szocializációt kulturális átörökitésnek tekintik - az enkulturácio kifejezéssel szinonim fogalomként használva -, és érdeklődésük középpontjába a különböző átmeneti rítusok tanulmányozását állítják, különös figyelmet szentelve a gyermekkorból felnottorb való átmenek a gyermek megközelítés fó gyengeśge a , knetnek (Sam 2006). E megközelítés fó gyengesége a „kulturális determinizmus," amely szerint az egyén passzív befog dó, személyiségét pedig a kultúra erói alakítják. Hála szimbolikus interakcionista tanulmányoknak - amelye Geertz (2001) munkájával kezdôdtek -, a mai kulturál antropológiában a szocializációt már a valóság közösségi megkonstruálása folyamatának tekintik, amelynek részét képezi a kultúra reprodukciója is. A szocializáció szociológiai értelmezése mindazokat a folyamatok hangsúlyozza, amelyek során az egyén megtanulja, miként illeszkedjen be a társadalomba (Lutfey-Mortimer, 2003). Az itt született kritikai tanulmányok érdeme az, hogy túlmutatva a kulturális antropológia eredményein, a figyelmet a történeti héttérre śs a hatalmi viszonyein ińný́tjék, amelyek az át iranyítjak, amelyek az átadott kulturális mintázatok és 1997). Állításuk szerint a szocializáció a társadalmi 1997). Alltásuk szenint a szocializáció a tarsadal diszkriminációt megerostó mechanizmus. Rámutatn a folyamat olyan rejtett aspektusaira, mint a szegregáció és a marginalizáció. Emellett peulg bevezetik a "túlszocializáltság" fogalmát is (Wrong, 1961), s figyelmeztetnek, hogy a funkcionalista értelemben sikeresnek nevezhetô szocializáció valojában abszolút integráciớ jelent, s ily módon a személyes identitás elvesztéséve jár, $\mathrm{s}$ ahhoz vezet, hogy az egyént a szocializáció tárgyaként kezeljük.'

A szocializáció tanulmányozása során - mindhárom fentebb említett társadalomtudományban - megváltozott az idő tényezójével kapcsolatos alapfeltevés, hiszen a szocialíaciót.

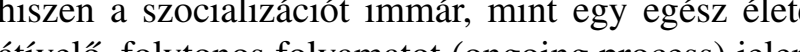
átíveló, folytonos folyamatot (ongoing process) jelen tették meg, amely men konatozódik a gyermekkorr Ennek nyomán pedig megnôvekedett az érdeklôdés felnőttkorban - külonosen a szervezeti környezetben végbemenő szocializáció iránt.

Szocializáció szervezeti kontextusban:

fogalmi tisztázás

Miután általánosan elfogadottá vált az a gondolat, hogy a gyermekkori szocializáció semmiképp sem ké- szítheti föl az egyént az élete során bekövetkező öszszes változásra, a szocializációval foglalkozó kutatások a felnôttkor - különösen pedig a munkahelyi szocializáció - felé fordították figyelmüket (Cohen - Scali, 2003, Lutfey - Mortimer, 2003). Itt két folyamatról van szó: szocializáció a munkára (socialization for work) es szocializáció a munkavégzés során (socialization by work) (Antalovits, 2001; Cohen - Scali, 2003). A munkára való szocializáción mindazokat az attitúdöket, értékeket és tudást értjük, amelyeket az egyén a családban a baráti körben és az oktatási környezetben cjútít el, még mielōtt a munka világúba belépnezetben szeme. Ezzel szocialijeli a fial jelzi, änelyek az iskolából a munkába való átmenet soTán következnek be (Antalovits, 2001, Cohen - Scali, 2003, Takács, 2006). Ez utóbbi folyamat foként a munkahelyi élet korai szakaszában érdekes, amelyet korai karrierszakasznak (early career stage) (Hall, 2002) vagy szervezeti belépésnek (organizational entry) (Van Maanen - Schein, 1976) is szokás nevezni.

Elismerem, hogy a pálya kezdetén szerzett szocializációs élmények erőteljesen befolyásolhatják a késóbbi szocializáció sikerét (Hall, 2002), valamint a készségek, attitúdök és a magatartás fejlôdését (Ruiz Quintanilla - Claes, 1995). Ily módon ez az idószak a Q Ger

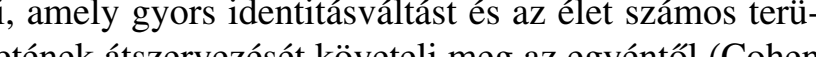
(Cohen Scali, 2003, Ivanov, 2003). Ugyanakkor azonban gyetértek Lutfey - Mortimer (2003) megállapításával, amely szerint a munkahelyi szocializáció folytonos folyamat, amely mindvégig tartalmaz olyan - talán nem egyformán intenzív - munkahelyi átmeneteket, mint az ujabb szervezetekbe való belépés, a kiküldetés vagy az elóléptetés. Ezeket a különféle munkahetyi váltásokat szakmai (occupational) vagy szervezeti (organizational) szocializáció címen tanulmányozták (Ashforth - Sluss - Harrison, 2007). A szakmai szocilizációs tanulmányok azoknak az értékeknek, viselkedéseknek és attitúföknek az elsajétításával fogiselke-

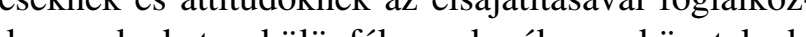
Í Igy példaul esettanulmányok születtek arról, miként lesz valaki halász Alaszkában (Bourassa - Ashforth, Anderagy könyveló (Ibarra, 1999, Fogarty, 2000; Anderson - Gough - Grey - Robson, 2001). Ezzel szemben a szervezeti szocializációs tanulmányok a munkára sajátosan jellemző tanulás mellett hangsúlyozzák annak fontosságát is, hogy az egyén elsajátítsa a szervezeti kultúrát és kiismerje magát a munkahelyen fennálló különféle hatalmi viszonyok között is. Ez a két folyamat véleményem szerint csak mesterségesen 
választható el egymástól, hiszen valójában egymás sal összefonódva jelennek meg. A legtöbb tanulmán aspektusát hangsúlyozza.

A következókben, tágabb megközelítést alkalmazva, a szervezeti szocializációt ${ }^{3}$ olyan folyamatnak tebelsó - határ átlépése jelzi (Van Maanen - Schein, amely révén az egyén a szervezetre jellemzó tevékenységi minta részévé válik" (Ashforth - Sluss - Harrison, ségi minta részévé valik" (Ashforth - Sluss - Harriso fentiekben megfogalmazott kérdésekre adott válaszo jelenlegi állását:

(1) a szocializációs folyamat folytonos - nem zárul le véges, előre determinált idóintervallumon belül, és az egyén lehet újonc vagy a szervezet veteránja, aki épp munkahelyi változást él át (pl. új osztály helyezik át, előléptetik, stb.),

(2) a szocializáció egyidejúleg különbözó közegekben történik (pl. munkacsoportban, szervezetben),

(3) a szocializálódó egyént (inter)aktív résztvevốne tekinti, nem pedig az információ passzív befogadójának egy viszonylag determinisztikus fejlődé modellben.

Mint ilyen, a szervezeti szocializáció egyúttal sikeresen épít az életciklus-szocializáció, a szakmai szociresen épít az életciklus-szocializáció, a szakmai szocializáció, a totális intézményekben való szocializáció
(Ashforth - Sluss - Harrison, 2007) és a csoportszoci(Ashforth - Sluss - Harrison, 2007) és a csoportszoci2006 ) területeken elért kutatási eredményekre, valamin
az elóző́ekben felvázolt tudományterületek hagyományaira. Mielőtt azonban a bevezetóben megfogalmazo kulcskérdések mentén részletesen bemutatnám a folyamatra vonatkozó releváns ismereteket, először áttekintem a szocializációhoz szorosan kapcsolódó más fogalmakat és meghatározom a köztük levő különbségeket.

\section{Kapcsolódó fogalmak}

A szocializáció és az enkulturáció fogalmakat gyakran szinonimaként használják, ugyanakkor van közöttük egy fontos különbség is. Sam (2006: 19. o.) szerin az enkulturáció magába foglalja „,mindazt a tanulást, amely az emberi életben végbemegy, anélkül, hogy bárkinek kimondott szándéka lenne, hogy a szóban forgó tudást átadja." A szocializáció ezzel szemben feltéteújoncok valamiféle együttmúködését, $\mathrm{s}$ az utóbbiak konkrét oktatását és képzését is (Sam, 2006). A fenti két fogalommal egy további kifejezés is szorosan öszazonban a folyamatnak vagy az egyik, vagy a mási kintem, amelynek kezdetét egy szervezeti - külsó vagy 1979), valamint „közvetít egyén és szervezet között, és alizáció (Moreland - Levine, 2001; Myers - McPhee, lezi az egyén szándékos formálását, a „veteránok” és

szekapcsolódik, a kulturális tudásátadás egy további lehetséges folyamatát jelezve, ez pedig az akkulturáció Az antropológia hagyományainak megfelelóen, ha a folyamat egészében az elsődleges kultúrában megy végbe, akkor az enkulturáció a helyes fogalom, ha azonban egy másik, másodlagos kultúrával való érintkezés indítja be a folyamatot, akkor az akkulturáció fogalmát indokolt használni (Sam, 2006). Ezért számos menedzsmentkutató a szocializáció és akkulturáció kifejezéseket szinonimaként használja ${ }^{4}$, ugyanakkor a fogalom komplexitását sokkal jobban megragadja az a megközelítés, amely a szocialiźciót egy kettôs di a negkó-

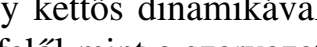
múbdón for a szervezet normán értelmezi, másfelól pedig mint a szervezet iránti attitúd szintú kötódés (attachement) kialakulását (Delobbe Vandenberghe, 2001). Ez utóbbit a szocializációs kutatások szervezettel való azonosulás (identification) ${ }^{6}$ , elkötelezódés (commitment) vagy a munkával való elégedettség (job satisfaction) révén operacionalizálják. Itt szeretném kihangsúlyozni, hogy a szervezettel való identifikáció (organizational identification) nem csupán a szervezeti szocializáció egyik lehetséges eredménye (lásd később a klasszikus szocializációs kutatásokat, mint például a szocializációs taktikák, szakaszmodellek), hanem a szocializációval párhuzamosan zajó és lek), hzon a szocialźciónal páthuzamosan zajló és szon azonos folyamatnak is tekintến A két folyan de nenzôti lényegi különbséget a fokuszba helyezett egyéni változások jelentik. Astor (2001) szerepek kozón átmenetek (role transitions) modellje szerint egy új szerepbe való belépés (ez lehet előléptetés vagy egy új szervezet is) az egyének négy alapvetổ szükségletét aktiválja: jelentés, kontroll, valahova tartozás (belonging) és identitás. Amíg a szocializáció proaktivitás vagy tartalmi modelljei a tanulási folyamatokat helyezik a középpontba, inkább az elsố három szükséglet kielégítésére fókuszálva (Ashforth - Sluss - Harrison, 2007), a legújabb kutatások az identitás (ki)alakulásának vizsgálatát részesítik elónyben (pl. Ibarra, 1999; Beyer-Hannah, 2002; Prit és tsai 2006; Bar (2007). Ezáltal sokkal tág és az identifikációra mintegy lényegi részfolyamatra te-
kintenek.

Összefoglalva: a „,Mit értünk szervezeti szocializáció alatt?" kérdésre keresve a választ meghatároztam a fogalmat, egyúttal kijelölve a továbbiak értelmezési keretét is, és a kapcsolódó fogalmak tárgyalása révén azt is tisztáztam, hogy mi nem tekinthetó annak. A továbbiakban a szervezeti szocializáció lényegi kutatási eredményeit és fordulópontjait fejtem ki a bevezetôben azonosított kérdések mentén'.

VEZETÉSTUDOMÁNY
Mi az idó szerepe a szocializációs folyamatban? Az idố tengely mentén a folyamat idốben való meghatározottságára (véges vs. folytonos) és az idô term szetére (lineáris vs. ciklikus) vonatkozó alapfeltevésekben történő változás jelöli ki a lényegi fordulópontot. A korai kutatásokban - szakaszmodellek - az idốt lineárisnak és végesnek tekintették, céljuk az általánosítható szocializációs szakaszok tartalmi és idóbeli meghatározása volt. A fordulópontot azon kutatások megjelenése jelentette, amelyek az általános érvényú szakaszok (ês hozzájuk rendelhető idôintervallumok) helyett a valos hozzájuk rón és az egyén számára kritikus idốt és az egyén számára kritikus szocializációs eseménulmányozva. Ez utóbbiak folytonos és nem feltétlenül lineáris folyamatot feltételeznek.

\section{Szakaszmodellek}

Már a kezdetektól számos kutató igyekezett úgy megragadni a szocializációs folyamatot, hogy figyelembe vették az időtényezôt is, annak függvényében határozva meg a szocializációs szakaszokhoz rendelhetô időintervallumokat, hogy mi történik a folyamat során, figyelmen kívül hagyva ugyanakkor a hogyan változik és miért kérdéseket.

Ezek a modellek általában négy szakaszt azonosítanak (az egyes tanulmányok között nincs egyetértés mind a négy szakasz tekintetében):

az elózetes szocializáció

a megismerkedés (encounter): valóságsokk, meg-

lepetés megélése (Louis, 1980); a szervezetbe

való belépést közvetlen követóen a munkaválla-

lók ütköztetik saját elvárásaikat a szervezet va-

lóságával és megteszik az elsô kísérleteket arra,

hogy szervezeti taggá váljanak,

a beilleszkedés (adjustment): egyéni és szerveze

akciók, amelyek célja, hogy az integrációt elóse-

gítsék, és

a stabilizálódás (stabilisation): olyan szerveze cselekvések, amelyek az egyén teljes befogadottságát jelzik (Fisher, 1986; Wanous, 1992; Bauer és tsai, 1998; Moreland - Levine, 2001; Ashforth - Sluss - Harrison, 2007)

Az első szakaszmodellt Buchanan (1974) fejlesztette ki, három szakaszt állapítva meg: beavatás (initiation); teljesítés (performance) és szervezeti megbízhatósấ (organisational dependability). Két évvel késóbb publikálta Feldman (1976) az egyik legnagyobb hatású szkaszmodellt, amelynek szakaszai az előzetes szocializáció (anticipation), az alkalmazkodás (accommodation) és a szerep betöltése és stabilizálás (role management)
Ezek a korai modellek empirikus kutatásokon alapultak és részletesen leírták az egyes szakaszokat, bár kevéssé tudtak megegyezésre jutni abban, hogy az elozzetes szocializáció vagy a stabilizáció (Buchanannál [1974] szervezeti megbízhatóság) is a folyamat részének tekintendô-e. Az elsôn nagy kutatási hullámot csönd követte. A szakaszmodellek megjelentek a szakirodalmi öszszefoglalókban (pl. Fisher, 1986; Bauer és tsai, 1998), továbbá új elméleti modellek jelentek meg, amelyek a olyamat más-más aspektusait hangsúlyozták. Így pl. zt, hogy hogyan küzd meg az egyén a szocializáció orán je (1987). Eze (N)

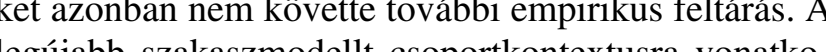
legújabb szakaszmodellt csoporkontextusra vonatkozóan alkották meg (Moreland - Levine 1982; 2001). Ezt alább az „Egy vagy több?” kérdés kapcsán részle-

Ezek a modellek kumulatív fejlődést feltételeznek, ahol az egyes szakaszok idốben követik egymást, és az elóző, sikeresen lezárult szakasz eredményeire építenek. Ezáltal a szocializációt egy pozitív eseménysornak tekintik, nem veszik figyelembe, hogy az egyénnel olyan negatív élmények is történhetnek (pl. a teljesítményére vonatkozó negatív visszajelzés), amelyek nem ak lever csak lé a Továbbá azt sem veszik figyelembe, hogy a szocializációs tartalom függvényében az egyên egy adott időpontban külonbözố szocializációs szakaszokban lehet. folyamatot idóben behatároltne tekent zajlása zajlása után - tehát, amikor az egyén már integrálódott - nincs szükség további változásra vagy fejlődésre (az egyedüli kivétel Moreland és Levine (2001), akik - jelezve, hogy a szocializáció egy folytonos folyamat modelljükbe illesztik az újraszocializálás szakaszát).

Ennek megfelelően a modellek fő hiányossága épp azzal kapcsolatos, amit hozzátesznek a szocializáció kutatásához: az idốtényezôt ugyan tekintetbe veszik, de inkább becslés, mint vizsgálat révén (pl a megis-

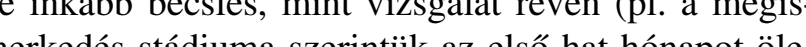

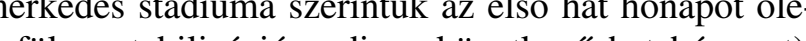
A sa stabilizáció pedig a kovetkezo hat hónapot) Azakaszmodellek egy másik fontos hiányossága, gogy a szervezetbe valo beilleszkedéssel (changing in) oglalkoznak, de az átalakulással (changing from) már nem (Louis, 1980).

Az átmenet rítusai (Rites of passage)

Az idôtengely mentén fordulópontot azon kutatások megjelenése jelentett, amelyek e kettós átmenet és a valós idó szerepének a megragadására helyezték a hang-

\section{VEZETÉSTUDOMÁNY}


súlyt, olyan kritikus eseményeket vizsgálva, amelye fordulópontként (turning points) szolgálhatnak, s ezze szakaszhatárokat jeleznek. Ennek egyik megvalósít si lehetôségét az átmenet rítusait vizsgáló etnográfi tanulmányok villantják fel. Ezek a kutatások kulturálsan érzékeny, részletes leírást kínálnak az ámenetekről, megragadva azon kritikus eseményeket, amelyek elvâlasztják egymástól a különböző szakaszokat: az elválás (separation), az átmenetet (transition) és a beolvasztást (incorporation) (Trice - Beyer, 1993). Az elválás „leválást, eltávolodást, elengedést" jelent (Louis, 1980) lôznie az új szerep betöltését. Kimondott elválási rítusokat olyan munkakörökben találunk, ahol közvetlen testi fenyegetés jelen van (pl. rendôrökél ( $V$ an Maanen, 1973); tüzotóknál (Scott - Myers, 2005) ,halászoknál" (halfeldogozás) (Bourassa - Ashforth, 2001)) vagy olyan esetekben, ahol erős negatív érzelmek is elófordulnak. (Cahil) [1999] pl. leírja, hogyan normalizálódik a haláltól és holttestekkel való munkától való félelem a halottkémnek tanuló egyetemistáknál.) Kevésbé hangsúlyos elvâlási rítusok gyakran előfordulnak más szervezetekbe is, ilyenek például az új helyszínekre való elutazás, régi szervezeti tagoktól elszigetelt környezetben zajló különféle tréningek. Minél egyedibb és erôsebb a szervezet kultúrája annál fontosabbak a szeparációs rítusok (Trice - Beyer, 1993). A második szakasz - az útus - idején az újonc maginális helyzetben van: atemenet idején az ú Ezet már nem, ú szervezeti szecepét még nem tôli be. Ezt a szakaszt illusztrálja nagyon hitelesen Bourassa Ashforth (2001) leirasa arrol, hogy hogyan szerezhe vissza személyes nevét egy új halász. Az átmeneti szakaszra vonatkozóan fontos szerepet játszanak azon kutatások, amelyek ezt a folyamatot „,szocializációs fordulópontok" soraként határozzák meg (pl. Bullis - Bach, 1989), és a fordulópontok (turning points) természetére, azok idóbeni maghatározottságára figyelnek. Így például Bullis és Bach (1989) tanulmányában a megkérdezet újoncok olyan eseményeket jelölnek meg szocializációjuk sarokköveiként, mint a saját fizikai környezet kiojuk sáso kénelmes rutinok kitalálása, formális és. formális társas összejöveteleken való részvétel, formális vagy informális elismerés, csalódások kezelése. Gundry és Rousseau (1994) pedig leírja, hogyan tanulják meg az és Rousseau (1994) pedig leírja, hogyan tanulják meg az
újoncok a szervezeti kulturát különböző „kritikus eseújoncok a szervezeti kultúrát különböző „,kri

mények" (critical incidents) dekódolása révén.

A fordulópont fogalmának a bevezetésével lehetóvé válik a szakaszmodellek által leírt folyamat idôben való finomhangolása. (1) Rávilágít az egyes szocializációs események idôzitésének a fontosságára (a közvetlen vezetó kemény kritikája az első héten lerombolhatja az újonc önbizalmát, míg az első félév után már fejlesztô lehetơségként szolgálhat (lásd Ashforth - Saks, 1997). (2) Nagy idóintervallumokat véve vizsgálódási alapkén (ahogyan azt a szakaszmodellek teszik) lehetôvé válik ugyan a folyamat általános leírása, de ez még nem teszi lehetővé annak megjósolását, hogy az egyes egyéneknek mikor mire is van szüksége. Ebben sokkal inkább segíthet a fordulópontok megfigyelése, amely lehetôvé teszi annak megértését, hogy az egyén hol tart a folyamatban. (3) A meghatározott idôpontban mért egyéni változók (pl. elégedettség, elköteleződés stb.) helyett ráirányítja a figyelmet az egyéni tapasztalatokra.

A beilleszkedési rítusok legtöbbször elmaradnak, A beilleszkedesi rínsok legtobbszor elmaradnak, (1993). Ez szertartás formáját öltik (Trice - Beyer, 1993). Ez utóbbit, ha a szocializáció korai szakaszában hasznáják, megfosztó taktikakén (es igy az átmeneti szakaszhoz köthetó, azzal az üzenettel, hogy „még nem tartozol közénk”), de késốbb már vizsgaként szolgál, azt teszteli, hogy az újonc mennyire azonosult az új szereppel.

\section{Egy vagy több?}

A második tengely mentén a szervezeti kontextus egységes vagy differenciált jellegének a szocializációs folyamatra gyakorolt hatására világítok rá Az intézményesített szocializációs taktikák az elóbbit felételezik, azon alapfeltevéssel élve, hogy a tatikák a

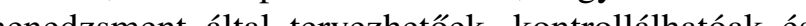

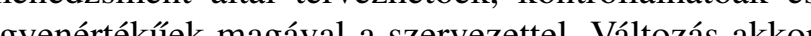
eövetkezett be, amikor a kutáḱ elfogadták, hogy a

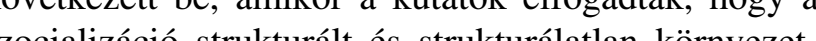
nen is történ strukturalt és strukturálatlan könnyezetjes is torten ik, anelyeket a menedzsment nem tud teljesen ellenőrizni, és a hangsúlyt a lokális kontextusra és a fontosabb szocializáló szereplókre (pl. közvetlen felettes, munkatárs) helyezték.

Szocializáció egységes szervezeti kontextusban: intézményesített szocializációs taktikák

A szocializációkutatás egyik legaktívabb területének múvelóit az foglalkoztatja, hogy a szervezetek miként struktuŕlják az újoncok szocializációs környezetét különböző szocialiź́ciós techikák alks koneze-

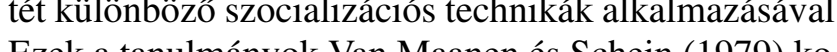
Ezek a tärón 1986; Allaban leirt modellre épulnek (például Jones, 1986; Allon- Meyer, 1990; Ashforh - Saks, 1996 ; Ashforth - Saks - Lee, 1998; Cable - Parsons, 2001; Kim - Cable - Kim, 2005; Gruman és tsai, 2006; Saks - Uggerslev - Fassina, 2007). A szocializáció itt alkalmazott tipologiája ,„a szervezeti szocializációs folyamat srukturáajara és eredményére vonatkozó, egymással kölcsönös összefüggésben álló elméleti felvetéseket" vázol föl (Van Maanen - Schein, 1979: 214. o.).
A modell hat bipoláris taktikát határoz meg, amelyeket a szervezetek felhasználhatnak az újoncok szocializációs tapasztalatainak strukturálására:

(1) kollektív-egyéni (collective vs. individual): az újonnan felvett munkavállalókat egy csoportként kezelik és a többi szervezeti tagtól elkülönítve közös élmények során vezetik végig óket, így a folyamat végén hasonló tapasztalatokkal, ismeretekkel rendelkeznek, vagy minden friss belépốt egyedi folyamaton visznek végig,

(2) formális-informális (formal vs. informal): az új belépóket elkülönítik a szervezet régebbi tagjaitól egy meghatározott (szocializációs) időszak végéig vagy nem,

(3) sorozatos, egymást követố-véletlenszer (sequen-tial vs. random): rögzített sorrendben lezajló lépések összessége, melyeket az új munkavállalónak teljesítenie kell egy adott szerep, státus betöltésének érdekében, vagy az esemenyek sorrendje változó, az új dolgozó számár nem létezik követendố minta, sorrend,

(4) állandó-változó (fixed vs. variable): előre meghatározott idóintervallumot rendel a folyamahoz vagy sem,

(5) folyamatos-megszakitott (serial vs. disjunctive): a régi szervezeti tagok tanítják-e be az új belepóket vagy a folyamatban nem használnak szerepmodelleket,

(6) felavató-megfosztó (investiture vagy divestiture): elismerik és erôsítik az újoncok meglévô képességeit és identitását, vagy tagadják ezeket és megfosztják tôle az új tagokat.

Annak ellenére, hogy Van Maanen és Schein (1979) már korai munkájában gondosan rámutatott arra, hogy az általuk áttekintett taktikákon kívül létezhetnek más szervezeti gyakorlatok is, a fent említett hat taktik napjainkig széles körben alkalmazzák.

A szocializációs taktikákkal foglalkozó kutatások három fó kérdésre keresik a választ:

(1) hogyan befolyásolják a különböző taktikák kívánatosnak tartott szervezeti és egyéni eredményváltozókat (pl. Ashforth - Saks, 1996; Jones, 1986),

(2) mely taktikák gyakorolják a legnagyobb hatást a kívánatos eredményváltozókra (pl. Allen - Meyer, 1990; Cable - Parsons, 2001; Saks Uggerslev - Fassina, 2007), és

(3) függetlenek-e egymástól a fentebb leírt taktikák (Jones, 1986; Ashforth - Saks - Lee, 1997).

Annak ellenére, hogy léteznek kutatási eredmé- nyek, amelyek a hat taktika függetlenségét bizonyítjak (Ashforth - Saks - Lee, 1997), számos kutató építi munkaját a Jones (1986) átal definiált kategóriákra (pl. Allen - Meyer, 1990; Cable - Parsons, 2001; Kim Cable - Kim, 2005). Jones (1986) szerint a hat taktika egy bipoláris tengely - aktív együttmúködés (agency continuиm) - végpontjai mentén helyezhetố el. A kolektív, formális, sorozatos, egymást követő, állandó, folyamatos és felavató taktikák információt kínálnak zújoncoknak, és arra ösztönzik óket, hogy passzívan elfogadják jelenlegi szerepüket, így fenntartva a status

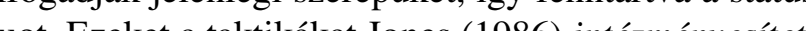
crocializ

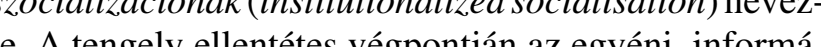
e. A tengely ellentétes végpontján az egyéni, informáin, vele lenszeru, váloź, megszakifto es negfosztó taktikákat találjuk, amelyek a status quo megkérdójeezésére osztönzik az újoncokat, és arra, hogy saját váaszokat fogalmazzanak meg a szervezet által támasztott elvárásokra. A taktikák e csoportját Jones (1986) egyéni (spontán) szocializációnak (individualized socialization) nevezte. Az intézményesített taktikák strukturált és előre megtervezett szocializációs folyamatról árulkodnak, míg az egyéni (spontán) szocializációnál a struktúra hiányát figyelhetjük meg: itt az újoncokat inkább a jó szerencse, mint az emberi tervezés céíti hozzá a jó hozy megfeleló módon szocializá lódjank (Akforth - Saks - Lee, 1997). A mecialozztó

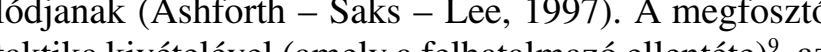

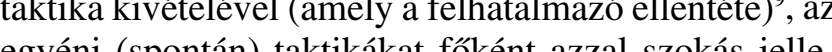
gyéni (spontann) takikákat toként azzal szo A kogy ni nem mondható el róluk.

A következókben az intézményesített szocializációs taktikákkal foglalkozom, amelyek révén a szervezetek az újoncok szocializációs környezetét strukturálják. Az itt bemutatott elméletek azokkal a lényeges elófeltevésekkel élnek, hogy e taktikák által létrehozott szervezeti környezet leképezi magát a szervezetet, valamint, hogy ezt a környezetet a menedzsment tervezi és koordinálja. Az intézményesített szocializációs taktikák a szocializáció egyik legaktívabban kutatott területét jelentik. Amint az elóbb láttuk, az elméleti alapokat Van Maanen és Schein (1979) fektette le, az empirikus kutatásokat pedig Jones

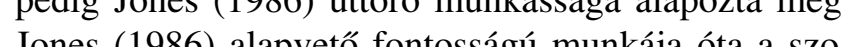
Jones (1986) alapvető fontosságú munkája óta a szocializációval kapcsolatos tanulmányok fókent az intézményesített taktikák és a kivanatosnak tartott eredményváltozok közôtti összefüggésekkel foglalkoztak (s ezek kivétel nélkül a Jones (1986) által kifejlesztett kérdôív eredeti vagy módosított változatait használták a hat taktika mérésére). Ezek a kutatások csupán újabb eredményváltozókkal bővítették a korábbiakat (Saks Uggerslev - Fassina, 2007), mint például a teljesítmény, a szervezettel való azonosulás (elsôként: Ashforth - 
Saks, 1996), valamint az észlelt személy-szervezet itleszkedés ( $P$-O fit) (elsóként: Cable - Parsons, 2001) így csak korlátozottan bővítve a szocializációs taktikák dinamikájának megértésére vonatkozó ismereteinket. A kutatási eredmények bizonyítják, hogy az intézményesített taktikák alkalmazását követően:

- az újoncoknál alacsonyabb a szerep-kétértelmúség (role ambiguity), a szerepkonfliktus (role conflict) és a szervezetbốl való kilépésnek a szándéka (intention to quit) (Asforth - Saks, 1996; Laker - Steffy, 1995), ugyanakkor

alacsonyabb a szerepinnováció ${ }^{10}$ (role innovation) is (Allen - Meyer, 1990; Ashforth - Saks, 1996; Black - Ashford, 1995; Jones, 1986), de

magasabb a munkahellyel való elégedettség (job satisfaction) (Ashforth - Saks, 1996; Laker Steffy, 1995),

magasabb a szervezettel való azonosulás (organizational identification) (Ashforth - Saks 1996),

magasabb a személy és szervezet közötti illeszkedés az új belépók saját észlelése szerint ${ }^{11}(P-O$ fit perception) (Cable - Parsons, 2001) és a személyes ertékrend fokozottan tolódik el az érték kongruenciája irányában (Cable - Parsons, 2001).

Így Van Maanen és Schein (1979), valamint Jones (1986) elôzzetes elméleti megfontolásaival összhangban az egymást követő kutatások bizonyították, hogy a kollektív, formális, sorozatos, állandó, folyamatos és felavató taktikák csökkentik az egyéni bizonytalanságot és a szorongást, továbbá érzelmi és kognitív szinten egyaránt kötő́dést szülnek a munkakör és a szervezet iránt.

A fentiekben hivatkozott tanulmányok eredményeit azonban óvatosan kell kezelni, mert:

(1) A különböző taktikák és eredményváltozók közötti kapcsolatok megállapítására egyszerú kétváltozós korrelációkat használtak, s nem vették figyelembe a szocializációs taktikák között fennálló korrelációkat (Jones 1986; Allen - Meyer, 1990; Black, 1992), valamint a különbözó ered1990, Black, 192), valanint a kullonnbözó eredến

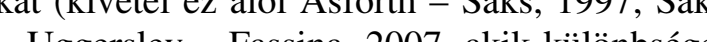
- Uggerslev - Fassina, 2007, akik különbsége tesznek a közvetlen [proximal] és a közvete [distal] eredményváltozók között)

(2) A fentebb említett ok-okozati összefüggéseke keresztmetszeti elemzések segítségével definiálták - Jones [1986] kérdốivének ${ }^{12}$ teljes vagy módosított változatai alapján -, amelyek Saks, Uggerslev és Fassina [2007] szerint erôsebb kapcsolatot mutatnak, mint a longitudinális vizsgálatok (kivételt jelentenek itt Allen - Meyer [1990] és Ashforth - Saks [1996] longitudinális vizsgálatai).

(3) Valamennyi vizsgálat amerikai posztgraduális (fóként közgazdász vagy MBA) hallgatók ${ }^{13}$ mintáin alapult (kivétel ez alól Black [1992] külföldön élő amerikaiak körében végzett vizsgálata, Klynn [2001] felsôvezetókön végzett vizsgálata és Bravo és tsai [2003] nyolc európai országból és két szakmából származó mintán végzett vizsgálata).

Ezek a tanulmányok a strukturált szocializációs köryezettel foglalkoztak, és a friss diplomás pályakezdók keresztmetszeti vizsgálata során (közvetlen) ok-okozati kapcsolatot kerestek a különféle taktikák és a lehetséges beilleszkedési eredmények között. Nem sikerült egyidejúleg beépíteniük az egyéni és szervezeti hatásokat, amelyek az elemzés különböző szintjein kölcsönhatásba lépnek egymással. További fontos hiányosság, hogy a szocializációs taktikákkal kapcsolatos kutatások - néhány kivételtoól eltekintve - nem adnak választ a következő kérdésekre:

(1) Milyen tevékenységek révén valósulnak meg a különféle taktikák (a meglévő tanulmányok afféle fekete doboznak tekintik ezeket)?

(2) Változnak-e idôvel a szocializációs taktikák (valamint ezek hatása a belépốkre), és ha igen, hogyan?

(3) Milyen típusú folyamatokat aktiválnak a különféle szocializációs taktikák (mögöttes mechanizmusok: miért és hogyan befolyásolják a szocializációs taktikák a beilleszkedési változókat)?

Mindent egybevetve megállapítható, hogy a szocializációs taktikák határozzák meg az új tagot váró kezdeti tapasztalatokat, ugyanakkor nem látunk rá azokra a mögöttes mechanizmusokra és üzenetekre, amelyek megmagyarázhatnák, hogyan értelmezik a résztvevók ezeket a tapasztalatokat.

Tekintettel a fentiekben megfogalmazott hiányoságokra, fontos fordulópontot jelentett az a felismerés, hogy az újoncok egyidejúleg strukturáluthon kontextusokba is belépnek, amelyek fölött a felsón vezetés nem bí ellenórzéssel (Hart-Miller, 2005). Ha elismerik bogy felsố vezetés terveitốl fügretlenül milyen kitu, hogy a fer jón

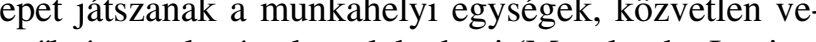

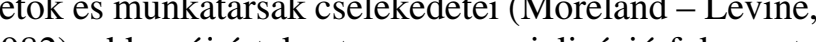
1982), akkor új értelmet nyer a szocializáció folyamata is. Igy azon elofeltevést is elvethetjük, miszerint az infaktikák a szervezet tétlenségéból ${ }^{14}$ fakadnának (Hart - Miller, 2005).
Szocializáció differenciált szervezeti kontextusban $\mathrm{Az}$ újoncokat különbözô szervezeti szereplók (p vezetốk, munkatársak, mentorok stb.) is segítik beilleszkedni azáltal, hogy információt kínálnak, szerepmodellként szolgálnak, vagy hozzáférést biztosítanak információforrásokhoz, informális hálózatokhoz, illetve más, a munkával kapcsolatos erőforrásokhoz (Major, 1995; Morrison, 2002; Kammeyer - Mueller és Wanberg, 2003). Ezek a tényezók kevésbé állnak a szervezet irányítása alatt (Cooper - Thomas és

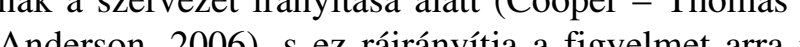
Anderson, 2006), s ez ráring (Cooper - Tho arra is, hogy az ujoncokat - a szervezet tervezett megnyil-
vánulásain túlmenốen - strukturálatlan interakciók is vanulásain túlmenóen - strukturálatlan interakciók is szocializáljak (Anderson - Thomas, 1996, Moreland Levine, 2001, Hart - Miller, 2005), amelyek inkább lokális kontextusokon alapulnak, mint a tágabb szervezeten (Ashforth - Sluss - Harrison, 2007).

A lokális kontextusnak a szocializációban játszott szerepéról megoszlanak a nézetek. Az első megközelítés azt feltételezi, hogy a szervezeti szocializáció javarészt a munkacsoportokban zajlik le (pl. Morelan - Levine, 2001; Moreland - Levine - McMinn, 2001), s odáig mennek el, hogy kijelentik: „a szervezeti szocializációval kapcsolatos írások jó része elhibázot" (Moreland - Levine 2001: 87. o.). Azt sugallják, hogy (Morelo - Levine 2001: 87. 0.). Azt sugallek, ho a munkacsopor

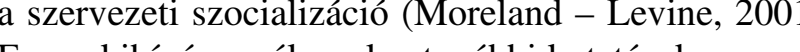
Erre a kihivásta valazzolva (Movabbi kutatasok megprobálták meghatározni a munkacsoport és a szervezet szintjén zajló szocializáció egymáshoz viszonyíto fontosságát annak mérésével, hogy mennyire elkötelezettek az alkalmazottak a munkacsoportjuk, illetve szervezetük iránt és mennyire illeszkedtek be ezekbe. Így például Adkins és Caldwell (2004) az újonco munkahelyükkel való elégedettsége és a munkacsoportba és szervezetbe való illeszkedésük közötti kapcsolatokat vizsgálta külön-külön. Értelmezhetô (regionális és szakmai természetú) kulturális különbségeket tudtak azonosítani a tanulmányozott munkacsoportok között, és azt toĺlták, hogy mindkét típusú kôzôtt, és azt találták, hogy mindkét típusú - munk za a munkával való elégedettséget. Ez azt jelzi, hogy a szervezeti értékek elsajátítása és a csoporttal való a szervezeti értekek elsajâtitása és a csoportlal való értekközösség egyaránt fontos - ez pedig ellentmon Moreland és Levin (2001) elózó álluásănak. Riket és Van Dick (2005) metaelemzésében bebizonyította, hogy az alkalmazottak erôsebben azonosítják maguk munkacsoportjukkal, mint szervezetükkel, de mindket azonosulás fontos szerepet játszik a különböző elemzési szinteken mért eredményváltozók alakulásában. A kapcsolatok erősebbnek bizonyultak, amikor az okokozati változók elemzési szintje megegyezett.
A fenti eredmények azt sugallják, hogy a szocializációs folyamatra mind a munkacsoporton belül, mind pedig a szervezetben zajló folyamatok hatást gyakorolnak, s így felvetődik az ezek viszonyára vonatkozó kérdés. Lehetséges válaszként Ashforth, Sluss és Harrison (2007) olyan modellt javasolnak, ahol a lokális szint közvetíti a kapcsolatot az egyén és a szervezet között. A folyamatok egyidejúleg, de nem azonos idôzítésben zajlanak (Anderson - Thomas, 1996). Ennek megfeleGon az alábbiakban áttekintem azokat a tanulmányoat, amelyek szerint az új belépók két párhuzamos belieszkési folyamaton mennek kerestiil: egyidejúleg (ép (ún A a szer arraba. A kutatások egyik lényeges alapfeltevése, hogy szervezetek különféle szubkultúrák gyújteményei $(\mathrm{pl}$. munkacsoport, szakmára vagy szervezeti egységre jelemzó szubkultúra stb.

A szocializációs kontextus természetére vonatkozó apfeltevések mentén két megközelítést különíthetünk el: (1) egyes tanulmányok a munkacsoporttal foglalkoznak, és figyelmen kivül hagyják a tágabb szervezeti kontextust és az esetleges csoportközi viszonyokat, míg (2) más kutatások a különféle szubkultúrákat, s ezek viszonyait is vizsgálják.

Az első megközelítésben két tágabb kategória küöníthetố el a választott módszer alapján: (1) kérdốves kutatások, amelyek a szocializációs folyamat és eredménye közötti ok-okozati kapcsolatot vizsgálják (pl. Moreland - Levine, 1982, 2001; Chen - Klimoski, 2003; Chen, 2005; Kroman - Myers - McPhee, 2006) es (2) longitudinális kvalitatív vizsgálatok a munkacsoportban zajló szocializációról, gyakran szakmai szocializáció néven említve ezeket, s gazdag leírást kínálva az egyének külonboozó kontextusokban szerzett élményeiról (pl. Holder, 1996; Anderson-Gough - Grey Robson, 2001)

Az első kategóriában a legnagyobb hatású elméleti modellt Moreland és Levine (1982; 2001) fejlesztették ki, akik a szocializációra a következő meghatározás adták: kölcsönös alkalmazkodási folyamat, amely jló változásokat hoz egy egyén és csoportközötti kapesolba" (Moreland - Levine 2001 :

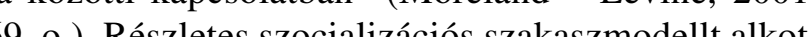

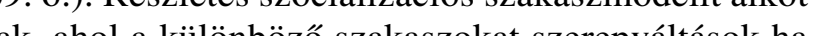
tárolják el egymástól. Az általuk definiált sza

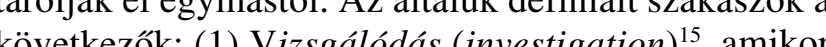
következók: (1) Vizsgálódás (investigation) ${ }^{15}$, amikor az egyen felméri a kulonfele csoportokat, a csoport pedig a maga részéról toborzással van elfoglalva, $\mathrm{s}$ az egyénre, mint lehetséges tagra tekint. (2) Szocializáció (socialization) ${ }^{16}$, amikor a csoport megtanítja az új tagnak az elvárt viselkedéseket, gondolkodást és érzéseket, az egyén pedig igyekszik olyan irányban befo-

\section{VEZETÉSTUDOMÁNY}


lyásolni a csoport elvárásait, hogy az a saját érdekeivel egybeessék. (3) Fenntartás (maintenance) ${ }^{17}$, amely során az egyén szereptárgyalásba fog, hogy a csopo teljes jogú tagjává válhasson. (4) Újraszocializálás $r a^{19}$ (resocialisation) akkor kerül sor, ha az elóző szakaszra jellemző teljes tagság nem valósult meg, vagy ezt a csoport megkérdójelezte (az egyén marginalizál tag lett), ily módon a csoport és az egyének második esélyt adnak egymásnak, hogy a teljes tagság megvalósulhasson. (5) Visszaemlékezés (remembrance) az után, hogy az egyén elhagyta a csoportot és volt tagga után, hy a egyen ellogyta a csoportot és volt tagg alakult át. Ás három fő folyav folyanatokra helyezi a a

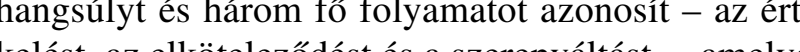
kelést, az elkôtelezóst és a szerepwálást -, amelyek tartósan jelen vannak mindaddig, amíg a tagok kilépnek a csoportból, legjobban pedig kisméretú, önkéntesen szervezodó csoportokra alkalmazhatóak. A mode empirikus vizsgálatára eddig kevés kísérlet történ (kivételként lásd Kroman - Myers - McPhee, 2006). Továbbá a modell attitúdbéli eredményváltozókra koncentrál, és nem foglalkozik a folyamat közvetle eredményeivel. Ez utóbbi hiányosságot korrigálja Chen és Klimoski (2003), akik az új tagok teljesítményét vizsgálták, mint a munkacsoportban zajló szocializáció sikerének közvetlen eredményét.

Tanulmányuk további érdekessége, hogy a szocializációs tanulmányok története során elôször határozták meg a teljesítményt mint sokdimenzió fogalmat, amelyben a munkakör, a karrier, az innováció, a csapat, a szervezet és az ügyfél-központúság egyaránt konkrét, elkülönüló teljesítmén változók. Azt találták, hogy az újoncok korább tapasztalata befolyásolja a csapat elvárásait, amelyek pedig erős közvetlen és némileg gyengébb közvetett hatással (az egyén motivációi mint közvetítő tényezớk) vannak az újonc hosszú távú teljesítményére. A tanulmány lényeges hiányosságát - nevezetesen, hogy statikus és nem veszi tekintetbe a teljesítmén fejlódését - Chen (2005) orvosolta, aki azt vizsgálta, hogy az újoncok teljesítménye hogyan fejlő́dik szocializáció során. Longitudinális, tỏbb elemzés szinten ativeló modellt alkotolt és tesztelt az új tagok csoporthoz való alkal azkodásán leiráára. Az a kalmazkodást mint az újonc teljesítményváltozásána mértékét definiálta, ahol - mivel a szocializációt pozitívan közelítette meg - a változáson szúk értelemben javulást értett. Mindkét kutatás azt találta, hogy a szocializáció a korábbi tanulmányokban jelzettnél jóva rövidebb - két-három hónapos - folyamat, s amelle érvelnek, hogy párhuzamos, de eltéró ütemezésú folyamatok zajlanak a szervezet és a munkacsoport ko textusában.
Ezek a tanulmányok a szocializációt néhány változó mentén operacionalizálják, s további vizsgálatokra szó-

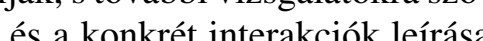
céljából. Ez vezet el a második kategóriába eső tanulmányokhoz, amelyek fóként a szimbolikus interakcionista hagyományon belül mozognak és a felfedezés nyers élményét hangsúlyozzák (pl. Hallier - James, 1999). Gazdag leírást kínálnak az átmeneti rítusokról és mindazokról a jelekról, amelyek mutatják, hogyan halad az egyén a tagóa válás útián mint például a zsargon S a történetek használata ( $\mathrm{pl}$. Hallier - James, 1999; Anderson-Gough - Grey - Robson, 2001; Bourassa Ashforth, 2001).

Egy messzire visszanyúló hagyományra építve ezek tanulmányok az intenzív és viszonylag durva szociizációs folyamatokkal foglalkoznak, s a szakmai alapon elkülönüló, piszkos munkával és alacsony preszizzsel együtt járó szubkultúrákat tanulmányozzák (pl. mészáros, temetkezési vállalkozó vagy börtönốr). A piszkos munka sajátos jellemzói - mint például a valós veszélyeztetettség, illetve a rendhagyó munkaidố vagy szokások - erôs szakmakultúrák kialakulásának kedveznek, ahol igen hangsúlyos az az érzés, hogy az érintettek elkülönülnek a szervezet fennmaradó részétól. Ezek a munkakörök megkövetelik, hogy az ốket betöltón egyének tomuják meg összeegyezeni saju betôn aját múködó emberi lény képét azzal a tevékenységgel, amit megélhetés céljábó vegeznek. Ha a szocializációra úgy tekintünk, min ezen szakmai szubkultúrákba való integrációra, igen fontos mogottes megkuzdési mechanizmusok kerülnek felszínre. Például Ackroyd és Crowdy (1990) a vágóhídi munkásokról szóló munkájukban leírják, hogy a pozitív identitás kialakítása céljából ezt a fizikailag és erkölcsileg egyaránt „piszkosnak” nevezhető munkát hogyan formálják át valódi, embert próbáló kihívássá, amely erő́t és szívósságot követel. Bourassa és Asforth (2001) hasonló szellemben írja le, ahogy egy alaszkai halászhajó újoncai kollektív és megfosztô technikák révén (pl. új fiúknak" nevezik óket, felszó(a) kapot is a buntetéseket is alakulnzek át tapasztalatlan egyénekból összetartó csapattá. Ezek az ujoncok szocializáciojuk során megtanulják megkérdójelezni korábbi identitásukat és felépíteni magukban egy talpraesett tengerész új identitását. A szocializáció tehát új, a munkából fakadó identitás kínált ezeknek az egyéneknek - a halász identitását -, $\mathrm{s}$ ez (a személyes identitással szemben) elsőrendú identitásukká lépett eló és segített a munkásoknak, hogy veszélyes, kimerító és kevéssé motiváló munkájukat megtanulják hősies és misztikus, férfias foglalkozásnak látni. Ez a tanulmány a szocializációt úgy láttatja, mint egy szakmai (szub)kultúrába való beilleszkedés folyamatát (halász), egyben pedig mint elhatárolódás (szembehelyezkedés) a halászhajón levő hatalomm bíró személyektốl (kapitány, szakács, ellenôrök), valamint a szervezettól is, amely halfeldolgozókként kezel óket, ily módon elóremutatva a második kategóriába tartozó tanulmányok felé.

Ezen tanulmányok mellett, melyek drámai és forradalmi átalakulásokat ragadnak meg, radásokat is azonosíth re tásokat is presztiźú csoportok szocializációja van: szakképzett diplomások vagy magasan képzett szakemberek mint a kônyvelók, menedzsment-tanácsadók vagy az orvo

A második megközelítésbe tartozó tanulmányok amelyek több szubkultúra létezését és a köztük levó i terakciókat is figyelembe veszik, a hatalom kérdésére is érzékenyen - azért fontosak, mert a szocializációt mint a szervezeti egyenlótlenségek újratermelésének folyama tát ragadják meg. Így például Anderson-Gough, Grey és Robson (2005) cikkében arról olvashatunk, hogy milyen erősen érvényesül a nemek szerinti differenciálás a nagy multinacionális könyvelócégeknél dolgozo ấa a nagy Dôn DiSanza (195) részo szocio bankyintézók szocializációjât elemzi két bankfióknál. A szerzô bemutatja, hogy az ujoncok hogyan szocializáló nak a banki ügyintézó szakmába és az egyes fiókokb eltérô és néha ellentmondó elvárásokkal szembesülve két szubkultúra tagjai részéról, miközben pedig elhatárolódnak a teljes munkaidóben dolgozóktól és a hierarchia magasabb szintjein állóktól.

Következésképpen elmondható, hogy ebben a megközelítésben a szocializáció egyszerre jelent integrácós és differenciációs folyamatot. Miközben az új tagok beilleszkednek a különféle szubkultúrákba, ugyanakkor azt is elsajátítják, hogy a csoport miként keres pozitiv jag el magának és hogyan határooportoktól. Ily módon a szocializácio a csoportok közötti egyenlótlenségek és konfliktusok fenntartásának és újratermelésének eszköze.

A folyamatot tovább bonyolítja, hogy az újonco az idốk során a különféle szubkultúráktól egymásna ellentmondó üzeneteket kapnak, s ez felveti az egyé megküzdési mechanizmusok kérdését. Ennek vizsgálatára teszek kísérletet jelen tanulmány következô részében, miközben arra is keresem majd a választ, hogy az egyének hogyan alakít(hat)ják a saját szocializáciơs folyamatukat.

\section{Lábjegyzet}

Ezt a hiányosságot részben orvosolja Erikson, aki pszichoszociális fejlódési fázisokról beszél, és azt állítja, hogy a szocializáció egész mindegyike egyeülŏ folyamat. Nyolc fázist különít el, amelyek kialakulása felé vezetố úton (1. Cole - Cole, 2006: 402. o.). A túlzásba vitt, teljes integrációt követelô szocializáció káro következményeit a totális intézményekról - börtönökról, pszichiátriai intézményekról - szóló tanulmányok írták le a legszemléletesebben.

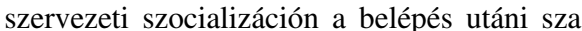

A legtöbb ilyen jellegú megközelítés az expatrióták szocializáciojaját vizsgáló kutatásokban található (1. pl. Atiyyah, 1996;

It fontos megkilonbōztetni az akkulturáció és asszimiláció fogalmakat, ahol ez utóbbi csak az egyiket jelenti a Berry (2006)

A szervezettel való azonosuláson azt értjük, hogy az egyén önmeghatározásáaban mekkora szerepet játszik a

Az utolsó kérdésre adott válasz kifejtésére a tanulmány második részében kerül sor.

Az egyes szakaszok részletesebb leírását l. itt: Fisher (1986); a szakaszmodellek történeti fejlódésének részletes leírása pedig az alábbi szövegben található: Ashforth - Sluss - Harrison (2007). A szakirodalomban vita folyik arról, hogy a felhatalmazó, illetve megfoszto taktika részét képezi-e az inteźzményesített szocializáciônak. Ashforth és Saks (1996) szerint a felhatalmazo taktika kutatások mintáját frissen vé́gzett közgazdászok jelentették. Feltételezik, hogy a szervezetek kimondottan a tanult képességeik és értékrendjük miatt alkalmaznak ilyen végzettségú diplomásokat, tehát az áll érdekükben, hogy megerósítsék ezen újoncok jellegzetességeit, ahelyett, hogy megkerdójeleznek (ezt az érvet cáfolni látszik Ivanov, 2003 kutatása, lásd a késôbbiekben). A totális intézményekben (pl. rendórséggel, túzoltósággal, katonasággal) végzett kutatások az intézményesitett szocializációs taktikákhoz az erôs szervezezti kultúŕ́valal, a sajátos szervezeti identitással és azzal, mennyire fontos szerepet játszik itt a kontroll (Ashforth - Saks - Lee, 1997). Ezért Ashforth, Sluss és Saks (2007) legutóbbi tanulmányában felveti, hogy a felhatalmazó taktika és a kívánatos eredményváltozók közötti kapcsolatnak külön tanul-

mányozása szuksegeges.
Ashforth és Saks (1996) elismeri, hogy az intézményesített takti-
kák kák egyaránt erősíthetik a szerepinnovációt és a konformizmust, folyamathoz de nem határozzák meg annak a konkrét tartalmás (az ́́tadott ïzeneteket nem tanulmányozź́k), s az intézményesített taktikák révén is a legkuilönfélébb üzeneteket lehet közvetí-

teni az új Szervezeti tagok felé.
Cable és Parsons (2001) kutatási eredményei szerint a pozitívan eszzlelt személy-szervezet illeszkedés korrelála a szocializáció társas es tartalmi taktikáival (konkrétan a sorozatos, állandó, folyamatos, felhatalmazó taktikákkal), de meglepó módon a kontextuáli takn (Saks - Uggerslev - Fassina, 2007).

nyesitett taktikák erốsebben befolyásolják a friss diplomásokat, 
mint a veteránokat (Saks - Uggerslev - Fassina, 2007) és (2) Ashforth, B.E. - Saks, A.M. (1996): Socialization tactics:

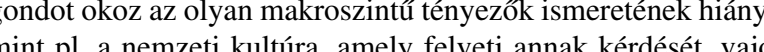
a szocializációs elméletek általánosíthatók-e különféle nemzeli kultúrákra (itt kivételt jelent Taormina [1999] tanulmánya a knai alkalmazottakról, illetve Bravo és tsai [2003] nyolc európ országot felöleló kutatása); ugyancsak problémás a nemzetköz beilleszkedés kérdésével kapcsolatos ismerethiány (kivételnek pl. a Black - Mendenhall - Oddou (1991) által a nemzetköz beilleszkedésre vonatkozó elméleti modelljét vagy Black (1992) tanulmányát az amerikaiak beil

Ez ellentmond Jones (1986) állitásának a szocializációs taktiké egydimenziós természetét illetớen (intézményes vios taktik taktika), valamint az Ashforth, Saks és Lee (1997) által nyúito értelmezésnek; és a VAGYlagos viszony helyett inkább az És kötôszót teszi indokolttá. A szerző amellett érvel, hogy a szocializációs kontextusok strukturalt vagy strukturálatlan volta „,egymással együtt járó és összefüggổ hatás", és figyelmünket e k aktika eltêró természetére és forrásaira irányítja.

dellekben az elózetes A

A stabilizálódásnak felel meg.

A szakembereket itt úgy határozzák meg, mint „ezoterikus tudással rendelkezó emberek csoportját, akik tudása gazdaság értéket képvisel, ha azokkal a problemakkkal szegezzük szembe (pl. beteggég), amelyekkel a társadalom tagjainak szembe kell
nézniük (Pratt - Rockmann - Kaufmann, 2006: 235. o.).

\section{Felhasznált irodalom}

Ackroyd, S. - Crowdy, P. (1990): Can culture be managed? Working with raw material: the case of the Englis slauterman, Personnel Review, 19(5), 3-13. old.

Adkins, B. - Caldwell, D. (2004): Firm or subgroup culture: where does fitting in matter most?, Journal o Organizational Behavior, 969-978. old.

Allen, N.J. - Meyer, J., P. (1990): Organizational socializatio tactics: a longitudinal analysis of links to newcomer commitment and role orientation, Academy of Management Journal, 847-858. old

Anderson-Gough, F. - Grey, C. - Robson, K. (2001): Tests of time: organizational time-reckoning and the making of accountants in two multi - national accounting firm Accounting, Organizations and Society, 99-122. old.

Anderson, N. - Thomas, H. D. C. (1996): Work group socialization, in West, M., A. (ed.): Handbook of work groups, Wiley, Chichester, 423-450. old.

Antalovits, M. (2000): Munkaköri/munkahelyi szocializáció, in Mészáros, A. (szerk.): Munkapszichologia, Szent István Egyetem szöveggyújteménye, Gödölló, 65-77. old

Ashforth, B.E. (2001): Role transitions in organization life: an identity-based perspective, Lawrence Erlbaum Associates, New Jersey

Ashforth, B.E. - Mael, F. (1989): Social identity theory and the organization, Academy of Management Review, 20-39. old. longitudinal effects on newcomer adjustment, Academy
of Management Journal, 149-178. old. Ashforth, B.E. - Saks, A.M. - Lee, R.T. (1997): On the dimensionality of Jones' (1986) measures of organizational socialization tactics, International Journal of Selection and Assessment, J (4), 200-214. old.

Ashorth, B.E. - Saks, A.M. - Lee, R.T. (1998): Socialization and newcomer adjustment: the role of organization context, Human Relations, 51(7), 897-926. old

Ashforth, B.E. - Sluss, D.M. - Harrison, S.H. (2007): Socialization in organizational context, in Hodgkinson, G., P. and Ford, J., K. (szerk.). International review of industrial and organizational psychology, vol. 22, 1-70. old. Ashforth, B.E.-Sluss, D.M.-Saks, A.M. (2007): Socialization tactics, proactive behaviour and newcomer learning: integrating socialization models, Journal of Vocationa Behavior, 447-462. old

tiyyah, H.S. (1996): Expatriate acculturation in Arab Gulf countries, The Journal of Management Development, 15(5), 37-47. old a reanalysis and reinterpretation using structural equation modelling, Human Relations, 48(2), 169-186. old.

Barbulescu, R. - Ibarra, H. (2007): Identity as narrative: overcoming identity gaps during work role transitions,

Bauer, T.N. - Morrison, E.W. - Callister, R.R. (1998): Organizational socialization: a review and directions for future research, in Ferris, G., R. (szerk.). Research in personnel and human resources management, CT: JAI Press, Greenwich, 149-214. old.

Beyer, J.M. - Hannah, D.R. (2002): Building on the past: enacting established personal identities in a new work setting, Organization Science, 13(6), 636-652. old.

Black, J.S. (1992): Socializing American expatriate managers overseas: tactics, tenure and role innovation, Group \& Organization management, 17(2), 171-192. old.

Black, J.S. - Ashford, S.J. (1995): Fitting in or making jobs fit: factors affecting mode of adjustment for new hires, Human Relations, 421-437. old.

Black, J.S. - Mendenhall, M. - Oddou, G. (1991): International adjustment: integration of multiple theoretical perspectives, Academy of Management Review

Bourassa, L. - Ashforth, B.E. (1998): You are about to party Defiant style: socialization and identity onboard an Alaskan fishing boat, Journal of Contemporary Ethnography, 171-196. old.

Bravo, M.J. - Peiro, J.M. - Rodriguez, I. - Whitely, W.T. (2003): Social antecedents of the role stress and career enhancing strategies of newcomers to organizations: longitudinal study, Work \& Stress, 195-217. old. the socialization of managers in work organizations, Administrative Science Quarterly, 533-546. old.
Baker, W.K. (1995): Allen and Meyer' 1990 longitudinal study:

Buchanan, B. II. (1974): Building organizational commitment:
Bullis, C. - Bach, B. (1989): Socialization turning points: an examination of change $\mathrm{n}$ organizational identification, Paper presented at the Annual Meeting of the Western Speech Communicalion Association, $1-38$. old.

Cable, D.M. - Pansons, C.K. (2001). Socialization tactics and Person - Organization fit, Personnel Psychology, 54(1), 1-23. old.

Cahill, S.E. (1999): The boundaries of professional socialization:The case of North American Funer Directors, Symbolic Interaction, 22(2), 105-119. old.

Chen, $G$. (2005). Newcomer adaptation in teams: multilevel
antecedents and outcomes, Academy of Management antecedents and outcomes,

Chen, G. - Klimoski, R.J. (2003): The impact of expectations on newcomer performance in teams as mediated by work characteristics, social exchanges and empowermen Academy of Management Journal, 46(5), 591-607. old.

Cohen - Scali, V. (2003): The influence of family, social and work socialization on the construction of the professional identity of young adults, Journal of Career Development, 29(4), 237-249. old

Cole, M. - Cole, S.R. (2006): Fejlóodéslélektan, Osiris Kiadó, Budapest

Cooper-Thomas, H. - Anderson, N. (2002): Newcomer adjustment: the relationship between socialization tactic, information acquisition and attitudes, Journal of Occupational and Organizational psychology, 423-438. old.

Delobbe, N. - Vandenberghe, C. (2001): La formation en enterprise comme dispositif de socialisatio organisationnelle: enquete dans le secteur bancaire, Le travail humane, 64(1), 61-89. old. (http://www.cairn. info/article.php?ID_REVUE=TH\&ID_NUMPUBLIETH_641\&ID_ARTICLE = TH_641_0061, letöltve: 03.08.2007

DiSanza, J.R. (1995): Bank teller organizational assimilation in a system of contradictory practices, Manageme Communication Quarterly, 9(2), 191-218. old.

Feldman, D.C. (1976): A contingency theory of socialization, Administrative Science Quarterly, 433-452. old.

Fisher, C.D. (1986): Organizational socialization: an integrative review, Research in Personnel and Human Resource Management, 4, 101-145. old

Fogarty, T.J. (2000): Socialization and organizational Managerial Issues, 13-33. old.

Geertz, C. (2001): Sứrú leírás. Út a kultúra értelmezó elmeletéhez, in: Az értelmezés hatalma, Osiris Kiadó, Budpest (eredeti: The interpretation of cultures, 1973, Basic Books, New York)

Gruman, J.A. - Saks, A.M. - Zweig, D.I. (2006): Organizational socialization tactics and newcomer proactive behaviors: an integrative study, Journal of Vocation Behavior, 90-104. old.

Gundry, L.K. - Rousseau, D.M. (1994): Critical incidents in communicating culture to newcomers: the meaning is the message, Human Relations, 47(9), 1063-1089.

(2002): Careers in and out of organizations, SAGE Publications, Thousand Oaks

P. in employee experiences of job change, Journal of Management Studies, 36(1), 45-67. old.

Hart, Z.P.Miller, V.D. (2005): Context and message content during organizational socialization: a research note, Human Commanication Research, 31(2), 295-309. old. Holder, T. (1996): Women in non traditional occupations: information seeking during organizational entry, Journa of Business Communication, 6-26. old.

anov, K. (2003): „Azt hittem, majd megváltom a világot”. Kvalitatív kutatás a közgázos pálykezdốk munkahelyi szocializaciojarórol, vezetestudomany, 34(11), 46-55. old. Jones, G.R. (1986): Socialization tactics self - efficacy and newcomer's adjustment to organizations, Academy of Management Journal, 262-279. old.

Kammeyer-Mueller, J.D. - Wanberg, C.R. (2003): Unwrapping the organizational entry process: disentangling multiple antecedents and their pathways to adjustment, Journal of Applied Psychology, 88(5), 779-794. old.

Kim, T.Y. - Cable, D.M. - Kim, S.P. (2005): Socialization tactics, employee proactivity and Person - Organization fit, Journal of Applied Psychology, 90(2), 232-241. old.

Klynn, B.J. (2001): Getting new executives on-board: investigating an integrated theory of socialization, $\mathrm{PhD}$ Thesis, Ohio State University

Rroman Myers, K. - McPhee, R.D. (2006): Influences on member assimilation in workgroups in high reliability organizations. a multilevel analysis, Human Communication Research, 440-468. old

Laker, D.N. - Steffy, B.D. (1995): The impact of alternative socialization tactics on self-managing behavior and organizational commitment, Journal of Social Behavior and Personality, 645-660. old.

Louis, M.R. (1980): Surprise and sense making: What newcomers experience in entering unfamiliar organizational settings, Administrative Science Quartely, 226-251. old.

Lutfey, K. - Mortimer, J.T. (2003): Development and socialization through the adult life course, in Delamater, J. (ed.): Handbook of social psychology, Kluwe Academic/Plenum Publishers, New York, 183-202. old.

Moreland, R.L. - Levine, J.M. (1982): Socialization in small groups: temporal changes in individual - group relations, Advances in Experimental Social Psychology, 137-192. old.

Moreland, R.,L. - Levine, J.,M. (2001): Socialization in Organizations and work groups, in Turner, M.E. (szerk.): Groups at work: theory and research, LEA Publishers, London, 70-112. old

Morrison, E.W. (2002): Newcomers' relationships: the role of social network ties during socialization, Academy of Management Journal, 45(6), 1149-1160. old. 
Myers, K.K. - McPhee, R.D. (2006): Influences on member assimilation in workgroups in high reliability organizations: a multilevel analysis, Human Communication Research, 32, 440-468. old.

Nelson, D.L. (1987): Organizational socialization: a stress perspective, Journal of Occupational Behaviour, 8, 311-324. old.

Nicholson, N. (1984): A theory of work role transitions, Administrative Science Quarterly, 172-191. old.

Pratt, M.G. - Rockmann, K.W. - Kaufmann, J.B. (2006): Constructing professional identity: the role of work and identity learning cycles in the customization of identity among medical residents, Academy of Management Journal, 49(2), 235-262. old.

Riketta, M. - Van Dick, R. (2005): Foci of attachement in organizations: a meta - analytic comparison of the strength and correlates of workgroup versus organizational identification and commitment, Journal of Vocational Behavior, 525-546. old.

Ruiz-Quintanilla, S.A. Claes, R. (1995): The impact of early career experiences on youth's proactive work socialization behaviour, CAHRS Working Papers Series, Working Paper 95-16., 1-36. old. (letöltve: www.ilr. cornell.edu/CAHRS/, 01.08.2007)

Sam, D.L. (2006): Acculturation: conceptual background and core components, in: Sam, D. L. és Berry, J. W. (szerk.): The Cambridge handbook of acculturation psychology, Cambridge University Press, Cambridge, 11-26. old.

Saks, A.M. - Uggerslev, K.L. - Fassina, N.E. (2007): Socialization tactics and newcomer adjustment: a meta - analytic review and test of a model, Journal of Vocational Behavior, 413-446. old.

Scott, C. - Myers, K.K. (2005): The socialization of emotion: learning emotion management at the fire station, Journal of Applied Communication Research, 67-92. old.

Somlai, P. (1997): Szocializáció. A kulturális átörökítés és társadalmi beilleszkedés folyamata, Corvina Kiadó, Budapest

Takács, I. (2006): A munkahelyi szocializáció és munkahelyi beilleszkedés pszichológiai tényezôii, in: Mészáros, A. (szerk.): A munkahely szociálpszichológiai jelenségvilága, Z-Press Kiadó kft., Budapest, 296-315. old.

Trice, H. - Beyer, J. (1993): The cultures of work organizations, Prentice - Hall, Englewood Cliffs, NJ

Van Maanen, J. (1973): Police socialization: a longitudinal examination of job attitudes in an urban police department, Administrative Science Quarterly

Van Maanen, J. - Schein, E.H. (1979): Toward a theory of organizational socialization, in Staw, B., M. (szerk.): Research in Organizational Behavior, Vol. 1, JAI Press, Greenwich, 209-264. old.

Wanous, J.P. (1992): Organizational entry: recruitment, selection and socialization of newcomers, AddisonWesley Publishing Company, London

Wrong, D.H. (1961): The oversocialized conception of man in modern sociology, American Sociological Review, 26(2), 183-193. old.

Cikk beérkezett: 2009. 3. hó

Lektori vélemény alapján véglegesítve: 2009. 5. hó 